\title{
The 2020 Election in Indian Country: Progress, but Equity is Still Elusive
}

\author{
JEAN SCHROEDEL | CLAREMONT GRADUATE UNIVERSITY \\ JOSEPH DIETRICH | CALIFORNIA STATE POLYTECHNIC UNIVERSITY, POMONA \\ KARA MAZAREAS | CLAREMONT GRADUATE UNIVERSITY
}

his past election season included the first ever presidential candidate forums devoted to Native American issues, one in July 2019 in Sioux City and a second in January 2020 in Las Vegas. The 117th Congress will include the first indigenous Hawaiian, as well as four Native Americans.' Representative Deb Haaland, who would have been the fifth Native American member of Congress, has been selected to lead the Department of Interior, which is another first for the Native American community. ${ }^{2}$ At the state level, nearly 100 Native Americans will take elected offices or serve in judicial roles starting in 2021. ${ }^{3}$ Finally, voter turnout among Native Americans appears to be at its highest level ever. ${ }^{4}$ All of these elements are signs of real progress with respect to Native American electoral participation, representation, and visibility, but there still are significant obstacles to equality.

Far too often, Native American attempts to register are derailed as nearly occurred in Minnesota, where a very successful Native-focused registration drive resulted in more than 8,000 completed forms-many of which were only accepted after threats of legal action. ${ }^{5}$ As has been true for a number of years, the closure of polling places, felony disenfranchisement laws, the purging of voter rolls, strict voter ID laws, non-standard addressing, and travel distance further impede access to the ballot box. ${ }^{6}$ What was new in 2020 was the increased importance of voting by mail (VBM), which was touted as a way for people to safely vote during the pandemic, but it is far from a panacea for Native communities that have been ravaged by COVID-19.? Voting rights attorneys argue that VBM imposes additional barriers to Native Americans' access to voting, due to the lack of home mail delivery, inability to get language assistance, travel distance to postal locations, and lack of reliable transportation. ${ }^{8}$

While examining all the possible barriers was beyond our ability at this time, there were some elements amenable to testing during the lead-up to the 2020 election. We decided to analyze access to mail services and the quality of those services by doing an in-depth analysis of differences between access for voters living on the Navajo Nation and those in nearby Arizona communities. The project is exploratory in terms of the target

Jean Schroedel is professor emerita of political science at Claremont Graduate University.

Joseph Dietrich is a researcher at Claremont Graduate University and is on the Department of Political Science teaching faculty at the California State Polytechnic University, Pomona.

Kara Mazareas is a student at Claremont Graduate University.

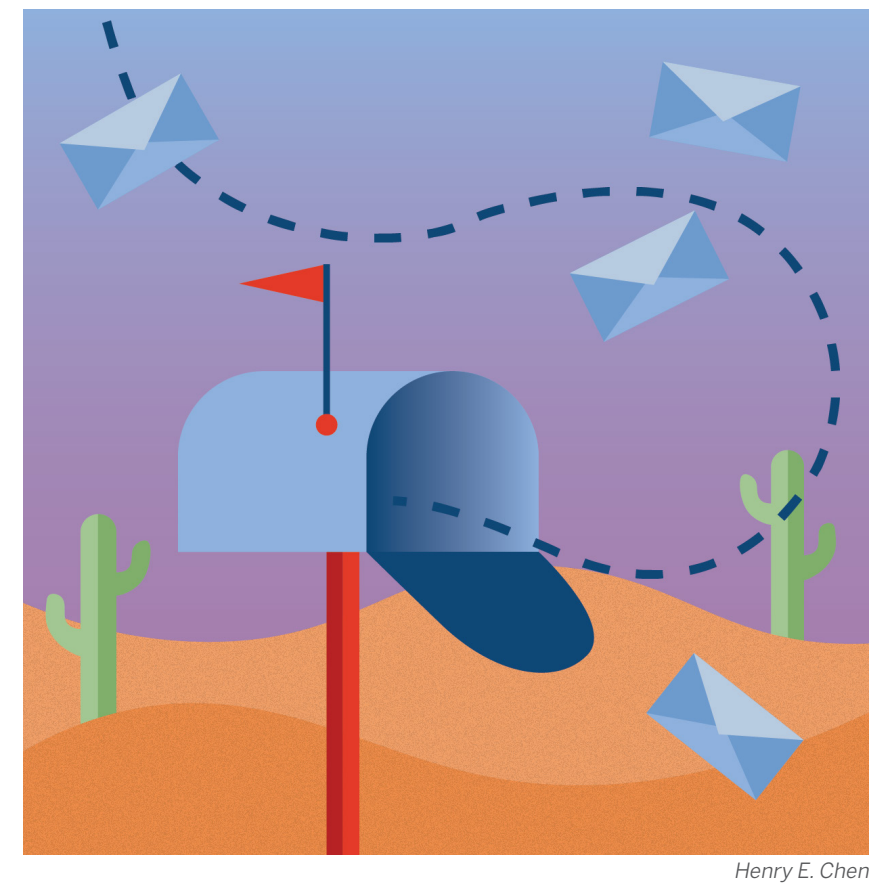

populations, but it fits within the well-established field of observational research in the social sciences. ${ }^{9}$ Funding was provided by an APSA Diversity and Inclusion Research Advancement Grant along with Four Directions, a Native American voting rights organization. Our preliminary findings show that voters living on the Navajo Nation face greater obstacles in votingby-mail than do off-reservation voters. We focused on two categories of barriers to participation: 1) access to mail services and 2) service delivery times.

The Navajo Nation, which encompasses 27,425 square miles, is slightly larger than West Virginia. Two-thirds of the reservation is in Arizona. Because there is no residential mail delivery, $\mathrm{Na}$ vajo must travel to post offices to receive mail, but according to the Navajo Nation President only about $10 \%$ of families have vehicles..$^{10}$ There are only 11 post offices and 16 postal provider sites" on the reservation in Arizona, as opposed to 725 in West Virginia. ${ }^{12}$ This translates into an average of one postal location for every 687 square miles on the reservation. Three precincts (Dennehotso, Mexican Water and Rock Point), which include a land mass of 871 square miles, do not have a single post office.

To test mail delivery, we did two rounds of mailing letters, with tracking from different locations on and off-reservation to 


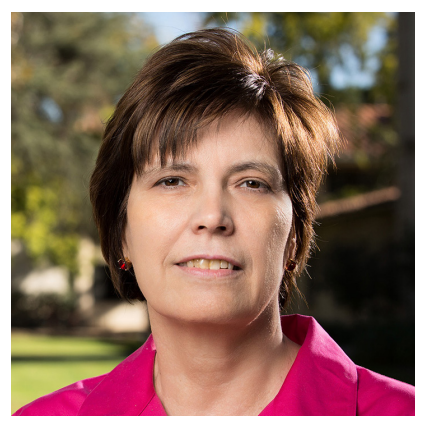

Jean Schroedel
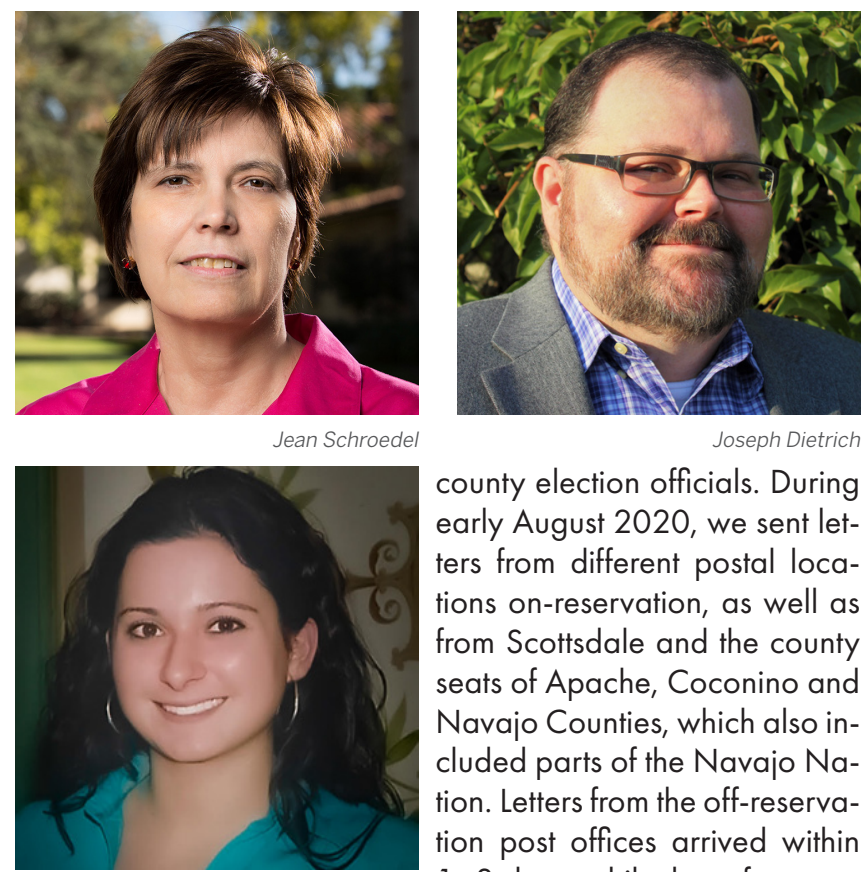

county election officials. During early August 2020, we sent letters from different postal locations on-reservation, as well as from Scottsdale and the county seats of Apache, Coconino and Navajo Counties, which also included parts of the Navajo Nation. Letters from the off-reservation post offices arrived within 1-3 days, while those from reservation sites took much longer, up to 10 days, including one that traveled 3,358 miles before getting lost. We did a second round of mailings on October 27,2020 , the date identified by the Secretary of State as when mail-in-ballots needed to be sent to assure their arrival by Election Day. We included a broader mix of off-reservation postal locations to ensure that we had a representative sample of rural, suburban and urban postal locations, as well as additional reservation locations. Every off-reservation letter arrived within 1-3 days, but the reservation ones again took significantly longer, and one did not arrive at all. The average delivery time for certified first-class mail was approximately 39 hours from urban post offices, 49 hours from off-reservation rural post offices, and 113 hours from post offices on the reservation.

This research also highlights the persistence of racially biased structural inequities, in terms of government services, which continue to shape people's lives. Most western post offices were established between 1840 and 1900, when they served as important conduits for economic development, connecting miners, ranchers, and soldiers. ${ }^{13}$ Post offices were not established on reservations until much later. For example, in Apache County, the off-reservation town of Concho (population of 116) has had a full-service post office since $1881 .{ }^{14}$ Teec Nos Pos (population of 793), on the reservation, did not get a post office until 1961 and it still provides less service than Concho. ${ }^{15}$ Our tracking showed that certified first-class mail to the County Recorder's office from Teec Nos Pos took over twice as long as it did for the equivalent mail from Concho.

Even though the state and federal officials responsible for initially institutionalizing those biased structural disparities are long dead, their racial animus still affects the lives of Native people in very real ways. Pierson describes this as the "stickiness of history" that inhibits social change even after the initial impetus was generations back. ${ }^{16}$ Both the nature of mail service on reservations generally and its implications for equal voting access in 2020 have been shaped by racially discriminatory policies of the past that are carried forward in often un-recognized ways. The layers of institutional prejudice endure within our administra- tive and cultural systems in both crude and subtle ways. At this historical moment it is crucial we address both overt and subtle forms of racism that continue to perpetuate injustice, including those present in unassuming institutions, such as the postal service.

NOTES

1. Caitlin O'Kane. 6 November 2020. "A Record-breaking 6 Native Candidates Were Elected to Congress on Tuesday." CBS News. Available at: https://www.cbsnews.com/news/six-native-americans-elected-to-congress-record-breaking

2. Cameron Jenkins. 11 November 2020. "Deb Haaland Says 'Of Course' She Would Serve as Interior Secretary Under Biden." The Hill. Available at: https://thehill.com/homenews/news/525434-deb-haaland-saysof-course-she-would-serve-as-interior-secretary-under-biden

3. Daniel Lathrop. 12 November 2020. "Native Candidates Score in Legislative, Other Bids." Indian Country Today. Available at: https://indiancountrytoday.com/news/native-candidates-light-up-state-local-ballots

4. Alexia Fernandez Campbell and Carrie Levine. 5 November 2020. "Native Americans, Hit Hard By COVID-19, Faced Major Barrier to Vote." Center for Public Integrity. Available at: https://publicintegrity.org/politics/ elections/ballotboxbarriers/native-americans-faced-major-barriers-to-vote-turnout/; Nora Mabie. 11 November 2020. "Analysis: Native American Voters in Montana Turned Out for Joe Biden, Democrats." Great Falls Tribune. Available at: https://www.greatfallstribune.com/ story/news/2020/11/11/election-2020-montana-native-american-voters-joe-biden-democrats/6163692002/; Anna V. Smith. 6 November 2020. "How Indigenous Voters Swung the 2020 Election." High Country News. Available at: https://www.hon.org/articles/indigenous-affairs-how-indigenous-voters-swung-the-2020-election

5. http://www.fourdirectionsvote.com/wp-content/uploads/2020/10/ MN-SOS-160ct2020.pdf

6. Jean Reith Schroedel. 2020. Voting in Indian Country: The View From the Trenches. Philadelphia: University of Pennsylvania Press.

7. https://caih.jhu.edu/programs/category/covid-19-response

8. Patty Ferguson-Bohnee and James T. Tucker. 2020. "Voting During a Pandemic: Vote-by-Mail Challenges for Native Voters." Arizona Attorney (July/August): 24-35.

9. Lynne E.F. McKechnie. 2008. "Observational Research," in The Sage Encyclopedia of Qualitative Research, ed. by Lisa M. Givens, pp. 573-75. Thousand Oaks, CA: Sage Publications.

10. Jonathan Nez. "Voting Rights and Elections: Administration in Arizona" (written testimony), quoted in Jason Chavez, "Inconvenient Voting: Native Americans and the Costs of Early Voting." MA Thesis, Virginia Polytechnic Institute and State University, 2020.

11. Postal providers are non-USPS contractors that offer limited mail services in non-post offices, such as mini-markets and gas stations.

12. https://www.postallocations.com/wv

13. Cameron Blevins. 2015. "The Postal West: Spatial Integration and the American West, 1865-1902." PhD diss., Stanford University.

14. https://www.census.gov/acs/www/data/data-tables-and-tools/da-

ta-profiles/; https://webpmt.usps.gov/pmt006.cfm

15. https://data.census.gov/cedsci/table? g=0400000US04_160000 OUS0472560\&d=ACS\%205-Year\%20Estimates\%20Data\%20Pro-

files\&tid=ACSDP5Y2018.DP05; https://webpmt.usps.gov/pmt006.cfm

16. Paul Pierson. 2004. Politics in Time: History, Institutions, and Social Analysis. Princeton, NJ: Princeton University Press, p. 8. 